\title{
A VÁLLALATOK POLITIKÁJA
}

\author{
VÁLLALATI, TÁRSADALMI FELELŐSSÉGVÁLLALÁS, \\ VÁLLALATI KÖZÖSSÉGEK ÉS \\ A VÁLlALATI STRATÉGIA JÖVŐJE
}

A vállalati társadalmi felelôsségvállalás (CSR) a diszciplinarizálódás korai szakaszában különbözố tudományos hagyományokból táplálkozva, a vállalatirányítás, az üzleti etika, a környezetgazdálkodás és a marketingkommunikáció határvidékének szélesítésével, különbözố hangsúlyú kiterjesztésével igyekszik saját helyét kijelölni a gazdálkodástudomány keretei között. Jelen tanulmány egy, az érintetti elméletekbốl kiinduló, ám alapvetốen történeti és politikai hagyományhoz köti a CSR jelenét és jövôjét, majd ebból a megközelítésból kiindulva helyezi el a CSR elméletét és lehetséges managementgyakorlatát a vállalatirányítás és a marketingkommunikáció világában. A szerzố álláspontja szerint a CSR inkább forma, mint tartalom; az üzleti értelemben vett fenntarthatóságot a vállalatok kevésbé jó ügyek képviselete révén, mint az érintetti (stakeholder) demokrácia megvalósulásának elósegítésével teremthetik meg. Jelen dolgozat azt mutatja meg, hogy az érintetti demokrácia mint üzleti múködési modell megvalósulása messzemenố következményekkel járhat mind a vállalatirányítás, mind a modern marketingkommunikáció számára. ${ }^{1}$

Kulcsszavak: CSR, érintettek, demokrácia, fenntarthatóság, márkaközösség, pluralizmus, $\mathbf{R}$ generáció, vállalatirányítás, vállalati társadalmi felelôsségvállalás

A vállalati társadalmi felelősségvállalásnak számos neve és arca ismert. Egyszerre jelent vállalati adományozást, ám egyben a vállalat versenyképességét támogató stratégiai eszköz is. Jelen írásban felvázolom a társadalmi felelősségvállalás (CSR - corporate social responsibility) kulturális, társadalmi és üzleti kontextusát, valamint állást foglalok a - jelenleg a diszciplinarizálódás korai szakaszában tartó CSR egy lehetséges értelmezésiránya mellett.

Az érintetti elméletekból kiinduló értelmezés nyomán kifejtem, hogy a CSR miként jelenthet kuhni értelemben paradigmaváltást az üzleti életben, illetve milyen változást hozhat a vállalati múködésben és üzleti együttmúködésben. Ezen változások kapcsán azt is jelzem, hogyan kapcsolódik a CSR managementje más érintettmenedzsment-területekhez, különösen a reputáció- és márkamenedzsmenthez.

\section{A társadalmi felelôsségvállalás, mint forma és tartalom}

A CSR fogalma sokféleképpen meghatározható: komplexitását talán a készülő ISO 26000 szabvány által alkalmazott definíció ragadja meg legjobban. Az ISO 26000 megalkotói szerint a CSR ,egy szervezetnek a társadalmat és a környezetet befolyásoló döntéseiért és tevékenységeiért tett felelósségvállalása olyan átlátható és etikus viselkedés révén, mely hozzájárul a fenntartható fejlódéshez - beleértve a társadalmi jólétet és egészséget is -, figyelembe veszi az érintettek elvárásait, megfelel az alkalmazandó jogszabályoknak és a nemzetközi viselkedési normáknak, a szervezet valamennyi területén integráltan megjelenik, és azt a vállalat kapcsolatain keresztül érvényesíti" (ISO, 2008: p. 3.). Ennél még egyszerúbben fogalmazva: a CSR az 
érintettek értékeinek és érdekeinek beépítése az üzleti múködésbe. Ehhez annak felismerésére van szükség, hogy a vállalat határai nem a vállalati kerítésnél húzódnak: a vállalat számos, különféle identitással rendelkező egyén és csoport életére van hatással, ahogyan e csoportok különféle módokon vannak hatással a vállalat múködésére. A vállalat mint érintettek összessége modelljét számos szerzô említi, legrészletesebb és legismertebb kifejtése Freeman érintetti szemléletû stratégiai menedzsment modelljében található (Freeman, 1984). Ezen elméletek a ma vállalatát többnek látják és láttatják, mint a részvényes által tulajdonolt transzmiszsziós szíj, mely áru vagy szolgáltatás munkavállalók és beszállítók általi előállítása, és azoknak a fogyasztók részére történő értékesítése révén teremt pénzben mérhetô értéket a részvényes (stockholder) számára. A részvényes mellett az értéklánc szereplói a vállalati múködés érintettjei is, hiszen kölcsönös hatások mutatkoznak a vállalat és az érintettek között, kölcsönösen rendelkeznek egymás számára szükséges eróforrásokkal, és fontos részei lehetnek az értékteremtési folyamat kontextusának, vagyis a vállalat szervezeti kultúrájának (Ferrell et al., 2010). Ez a vállalat múködésén túl hatással van az értékteremtési folyamatra is, vagyis az új vállalati múködés megértéséhez a vállalati értékteremtési folyamat új elméletének megértésére is szükség van.

$\mathrm{Az}$ ún. hármas eredménykritérium (triple bottom line) szemlélete szerint a vállalati értékteremtés folyamatának nem csupán a pénzügyi vagy gazdasági eredményességre kell kiterjednie. A pénzügyi siker mellett a vállalat eredményességének a társadalmi és környezeti teljesítményében is mérhetônek kell lennie (Elkington, 1998). Ezen eredményességszemlélet vagyis az értékteremtési folyamat eredményének mérése - jelenik meg a 3P (people, planet, profit) elvben, mely a fenntarthatóság (sustainability) alapszemlélet módjává vált. Ennek alapján nem csupán a pénzügyi tốkét kell eredményesen múködtetni, hanem hasonló eredményességi elvárások fogalmazódnak meg a humán- és a környezeti tókével szemben is (UNWC, 1987). A vállalatok társadalmi felelôsségvállalása tehát egy másik lehetséges meghatározás szerint az érintettek hatékony menedzsmentje annak érdekében, hogy a vállalat minél eredményesebben feleljen meg a hármas eredményesség szempontjainak.

A vállalatok azonban csakúgy, mint az intézményi érintettek, továbbra is küszködnek azzal, hogy a társadalmi felelősségvállalást fó üzleti tevékenységük részévé tegyék, s így számos, a társadalmi felelősségvállalás stratégiai megközelítése által nyújtott potenciális lehetőségtól esnek el (Porter - Kramer, 2006).
Meggyőződésem szerint ez azért alakult így, mert bár sokan tartják a CSR-t a XXI. századi vállalatirányítási gyakorlat szempontjából nagyszerú lehetôségnek, még mindig nem látják a vállalati múködés új megközelítésében rejlő paradigmaváltást. A CSR hatásai és a CSR-ból fakadó változás még annál is sokkal sarkalatosabb lehet, mintha a CSR körüli viták során egy, a vállalatokra vonatkozó új elmélet jelent volna meg. Ugyanakkor sokan állítják, hogy a jelenlegi válság nem kedvez ilyen új elméletek megjelenésének, és a CSR sem válhat a közeljövő́ben általános üzleti gyakorlattá, ehelyett a vállalatok múködési és vállalatirányítási gyakorlatukban visszatérnek az alapokhoz.

A CSR inkább forma, mint tartalom: a CSR olyan folyamat, melyben az érintetti elvárások a szervezet minden területén integráltan megjelennek, és sokkal inkább a kapcsolatokban érvényesül, mint közvetlen módon; hatása pedig a fenntartható fejlődés elósegítésére irányul. Egyes társadalmilag helyes elvek - a társadalmi integráció, környezetvédelem, az AIDS, az éhínség és a társadalmi egyenlőtlenségek elleni harc (vagyis a tartalom) - üzleti múködésbe történó beemelése helyett itt az érintettek egyetlen közös, értékteremtő cél köré csoportosításának új formájáról van szó. A hármas eredményességnek való megfelelés az érintettek hatékony menedzsmentje, vagyis stratégiailag végiggondolt, mérőszámokkal motivált, erőforrások által támogatott, folyamatok segítségével tervezett és eredményesen kivitelezett, majd visszamért tevékenység által valósul meg. Erre válaszul hozhatják egyesek a régi friedmani érvet, mely szerint az üzlet lényege csak a szigorúan vett üzlet, épp ezért a vállalatoknak nem feladata a társadalmi szereplőket és érintetteket egy közös cél köré szervezni. Ez - ahogy azt Friedman hívei tartják - a kormányok feladata lenne, hiszen ôk hivatottak a szociális teendốket intézni. Ugyanakkor a vállalatok a kormányoknál, vagy más társadalmi szereplőknél - ideértve a nem kormányzati szerveket, NGO-kat is - sokkal hatékonyabb szervezetek. Amint azt Jeffrey Swartz, a Timberland vezérigazgatója egyszer mondta: „A vállalatoknak annyi erósségük van - mint például az innováció, az eróforrások és a szakértelem - amelyek felhasználásával jóval többet is el lehet érni egy kiválo termék vagy szolgáltatás létrehozásánál. Ebben a világban élünk, és akár akarjuk, akár nem, hatással vagyunk rá... miért ne tegyük ezt a hatást annyira kedvezóvé, amennyire lehetséges - hiszen meg tudjuk tenni?" (Accountability, 2011)

A globális világ kihívásai a gazdasági múködés kontextusát is megváltoztatták: az éghajlatváltozás és ennek hatásai, Kelet és Nyugat meg-megújuló harca, a globális ,perifériákon” államok dezintegrációja, és az 
ebből fakadó „humanitárius katasztrófák”, az éhezés és a nyomor a harmadik világ számos részén, a digitális szakadék elmélyülése, és így az információs egyenlőtlenség növekedése, a hagyományos - elsősorban a nyomtatott - médiumok lassú halódása és az innováció hiánya új feltételeket teremtett a gazdaság szereplői számára. Mindez bizonytalanná teszi a jövőt, ami a remény és a bizakodás és (részben ennek következtében) a bizalom radikális eróziójához vezet. Mindebból az következik, hogy a gazdasági döntéshozóknak, vezetôknek nem türelemre, hanem stratégiai gondolkodásra van szüksége, az új állapot tünetei helyett a következményeivel, a jövő két fontos építókövével: a bizakodással és a bizalom újrateremtésével kell és érdemes foglalkozni.

\section{Megatrendek és generációs különbségek}

A jövővel kapcsolatos bizonytalanság abból is adódik, hogy nemigen van olyan kapaszkodó, mely segíthet az ismeretlen jövő megértésében. Negatív gazdasági spirálok, a piaci viszonyokat befolyásoló társadalmi környezet jelentős módosulásai, a felhasznált nyersanyagok kimerülésének veszélyei - ezek mind olyan körülmények, melyek jelentős változásokat indítanak el. E jelentős változásfolyamatokat nevezi a szakirodalom megatrendnek. Ma három megatrend csírái figyelhetôek meg: a közösségiség, a tudatosság és a fenntarthatóság megatrendjei. A közösségiség megértése a bizalom új csatornáit és formáit hozhatja létre - kevésbé a „valóságot” egyre jobban leíró információ mindenhatósága, inkább a közösség tagjainak nyilvános és közös cselekvései teremtik meg a bizalom helyreállításához szükséges közös meggyőzőóést. Az életminôségünket befolyásoló egyéni döntésekben megjelenó fokozott tudatosság - a fogyasztástól a lakóhelyválasztáson át, a munkahely megválasztásáig - új biztonságot ad: képes lehetek és vagyok befolyásolni saját életemet, újra saját sorsom és életem ura lehetek. A fenntarthatóság megatrendje az érintettek emancipációjának következménye: egyre több érintetti csoport és képviselőik, a globális és helyi nem kormányzati szervezetek (NGO-k) követelik meg, hogy értékeik és érdekeik megjelenjenek a különböző szintú döntéshozatali folyamatokban. $\mathrm{Az}$ érintettek hatékony menedzsmentje e megatrendek által teremtett kihívásoknak megfelel.

A hathatós CSR egy, a vállalatról és az ôt körülvevő világról szóló új víziót feltételez. A CSR paradigmaváltás a vállalatirányítási filozófiában és az üzleti stratégiában. Mindez nem automatikus folyamat. A vállalati döntéshozók - még - nem készek a paradigmaváltásra, ahogyan tulajdonosaik sem. A legtöbb felsô vezetô a baby boom generáció tagja, a '70-es években folytatott üzleti tanulmányokat, üzleti és MBA-tapasztalatait a '90-es években szerezte, vezetôi élményei pedig az ezredfordulóhoz kötődnek. Bár többségük felismeri azon problémákat, melyekkel napjaink társadalmai és vállalatai szembesülnek, tapasztalatuk, ismereteik és készségeik mélyen a régi paradigmában gyökereznek. Az ôket mostani „,székükbe” emelő sikerek egy teljesen másfajta társadalmi és üzleti környezetból származnak.

A háború utáni generációs felosztásban egyeloóre három fontos generációt szokás megkülönböztetni. A háború után, a hatvanas évek közepéig születố generációt, amikor az életszínvonal emelkedése bőséges gyermekáldást hozott, egy új, önmagát kulturálisan és gazdaságilag is öndefiniáló generációt teremtett: a baby boomereket, az X generációt, majd a mai fiatalokat, az Y-okat. A baby boomerek, ez a Magyarországon nagynak nevezett nemzedék kulturális gyökereit tekintve a szüloók elleni lázadás, a tehetség teremtette önállóság és felemelkedés generációja - a mai vezetốk jelentôs része e generáció tagja. A lázadás mára konformitássá és a status quo megốrzési vágyává vált, a vezetôvé válás sok tanulsággal és tapasztalattal járt, az építkezés kevésbé tudatos és tervezett volt. Miközben e generáció merészsége és bátorsága számos határt, falat és tabut döntött le a hatvanas években, meghatározó éveik és tapasztalataik - a lázadás éppúgy, mint a konszolidáció - egy más korhoz, a maitól jelentôsen eltérô technikai és kulturális kihívások világához kötik óket. A baby boomereket követô $\mathrm{X}$ generáció tagjainak, mai harminc-negyven éveseknek kevés lehetôségük volt a lázadásra, hisz épp a lázadás kultúrája teremtette meg számukra az élhető világot. A frusztráció lázadása így sokuk számára a szülő́k, a háború elótti generáció konzervativizmusához és hagyomány- és rendtiszteletéhez való visszatérést jelentette. Nemzetközileg e generáció kevesebb lehetőséget látott maga előtt, megélte, hogy a világ nem folyamatos fejlődés, és a jobb mód felé tett lépések sorozata, hanem válságok szabdalta lassú elôrehaladás, melyben a hosszabb visszalépés sem lehetetlen. Miközben technikai értelemben a világ kitárult előttük, fiatal felnôttként élték meg a számítógép és az internet elterjedését, a nyolcvanas, kora kilencvenes évek új, múszaki forradalmát, kevesen tudtak élni a szép, új világ kínálta lehetôséggel. Mai vezetôink egy része, valamint a baby boomerek mögötti második vonal generációja általában a fontolva haladás, a kísérletezés helyett a járt utat választás csapata - sok lelkesültséget látott és nagy bukásokat - a kelet-európai vadkapitalizmus és a dotkom válság élményeit megélt generáció ma inkább visszahúz és visszafog, kivár és remél. Az Y generációnak lázadás helyett csupán „bele kellett ül- 
nie a készbe", az előttük járók technikai és társadalmi bizonytalankodásai után e generáció már belenôtt az új világba: a technikai újdonságok számukra nem kihívást és lehetôséget, hanem hétköznapi készséget és természetes környezetet jelentettek. Az e-mail, az interaktív média, a tömeg és fogyasztás kultúrája, a szabadság és a szabadosság határainak elmosódása egyszerre tette e generációt befelé fordulóvá és kinyílóvá. Miközben elfordultak a hagyományos közpolitika és közgazdaság tereitôl, egy másik társadalmi tér, a közösségi média terei nyíltak meg elóttük vagy nyitották meg ôket maguk, maguknak. Nem felfelé és elốre, hanem oldalra és a jelenben beszélgetnek, kevés céljuk és sok érzékenységük, tudásuk, készségük van - az X-ek és a baby boomerek előtti egyik kihívás, hogy miképp tudják mindezt a közügyek szolgálatába állítani. Míg a baby boom idején született és az $\mathrm{X}$ generáció vezetói a régi paradigmát örökölték, egyre több alkalmazottjuk, fogyasztójuk és érintettjük gondolkodásmódja, fogyasztási szokásai és identitása alakult át teljes egészében. A baby boomerek az értékteremtést a folyamatos növekedésben, a pénzben elért sikerekben, az anyagi biztonság megteremtésében látják, a sikert a termelésben szerzett jártasság kínálja, a kommunikációt szükséges rossznak tekintik, a modern technológia és kommunikáció lehetôségeit ismerik, de nem élvezik, alkalmazzák, de nem használják. Számukra a munka világa adottság, az üzlet a „hivatali” megfelelés terepe, ahol a munka az első́, a jólét másodlagos. Az Y generáció már a nyílt kommunikációból gyarapszik, ért a médiához és információhoz, céljai eléréséhez kész együttmúködni, kapcsolati hálóját építeni és használni (networking), és vállalja az egymásrautaltságot; egyik fó értéke a munka-élet egyensúlyának (work life balance - WLB) megteremtésére való törekvés (Jorgensen, 2003).

Adódik a kérdés: ki következik? Kutatások azt mutatják, hogy a ma 14-18 évesek, az ezredforduló elôtt és utána születettek legalább olyan radikális generációvá válhatnak, mint a baby boomerek annak idején. Ốk azok, akik - a válság ellenére - jólétben és biztonságban nevelkednek, ugyanakkor látják a feszített világ teremtette külsố és belsố kihívásokat, már nem a felismerés örömével használják készségszinten a technikai lehetôségeket, látják a huszadik század második felének előnyeit és hátrányait egyaránt, mernek és tudnak kérdezni, néha olyanokat is, amire nincs könnyú és megnyugtató válaszunk. Azt vallják, hogy a munka van az életért, a múlt van a jövőért - nem az önmagáert való élményt, hanem a hétköznapi boldogságot keresik. Identitásuk, az elkülönbözés, és annak kifejezése fontos, mindenki egyenlő, és ezért lehet különböző. A fogyasztás nem szerzés, hanem egy közösséghez tar- tozás lehetôsége, a Hello Kitty, Bakugán nem szól semmiról, és ez jó így, mert azzal lehet megtölteni, amivel akarják, akik mi vagyunk vagy lehetünk. És legfő́képp: senki nem oldja meg helyettuik a világ problémáját: nem az államtól, a politikusoktól kell várni a megoldásokat, hanem nekik lehet és kell kitalálni, kikényszeríteni óket. Közösségeik ereje épp ebben van vagy lehet, képesek célokért összefogni, fogyasztóként, leendô munkavállalóként, mozgalmárként egyaránt. Az ô kultúrájuk nem a szembenállás és verseny, hanem az együttmúkködés kultúrája. Felelősek magukért, maguk választotta közösségeikért, jelenükért és jövőjükért, és tenni is hajlandók érte. Ốk lehetnek az R, azaz a felelős (responsible) generáció. $\mathrm{S}$ bár a betúk sorában (BB, $\mathrm{X}, \mathrm{Y})$ a $\mathrm{Z}$ generáció következne, ez a generáció lehet az, amely képes lehet kikényszeríteni, hogy az állam helyett a legnagyobb hatású társadalmi szereplôk, a fogyasztás kultúrájának ágensei, a társadalmi viszonyokat meghatározó foglalkoztatók, a legnagyobb fejlesztéseket, átalakításokat végrehajtók legyenek. Vagyis a modern vállalatok is a közösségek értékei mentén, velük együttmúködve feleljenek meg az elmúlt négyszáz évben elért gazdasági sikerek teremtette társadalmi kihívásoknak. Ók azok, akiket már nem elégít ki a márkák világában az érdek- (ár, szolgáltatás, minôség) alapú kapcsolat, mely a baby boomerek számára elegendő volt. Ahogy nem érdekli túlzottan óket a márkák teremtette érzelmi kötódés (kutya, gyerek, szerelem) sem; értékkapcsolatokra, márkaközösségekre vágynak, ahol óket is bevonva születik termék, szolgáltatás. Ahol a márkák bátran kiállnak értékek mellett, és ettôl lehet szeretni óket, ahol a márkákhoz tartozás értékállítást, és így értékkifejezést fogalmaz meg, ahol a márka az értékalapú identitás megmutatásának eszköze és nem a fogyasztás kultúrájának áldozatul esés jelképe. Az R generáció a fogyasztás kényszere alól mentené a fogyasztót. Ez nem a fogyasztás elleni harc, hanem az értékes fogyasztás melletti értékválasztás - a fenntarthatóság, a környezettudatosság, az elnyomásmentesség kultúrájának megjelenítése a fogyasztás kultúrájában.

\section{Idốutazás - abszolutista vállalatok és késố modern érintettek}

A ma egyik legfontosabb ellentmondása az, hogy óriási szakadék tátong a mai vállalkozások szerkezete, politikája és kommunikációja, valamint az óket körülvevó világ között. Egyszerúbben: bár XXI. századi társadalmi, politikai és kommunikációs környezetben élünk, a modern vállalkozások még mindig annak a kornak - nevezetesen a XVII. századnak - a teremtményei, melyben kialakultak. Így a CSR egyfajta kísérlet arra, hogy 
áthidalja a szakadékot a XXI. századi posztindusztriális késô modernitás és a modernitás születésének kora - a XVII. század között. A jó vállalatok stratégiai szemléletú vezetôi igyekeznek megérteni a vállalatukat környezó társadalmat, és olyan vállalati stratégiákat dolgoznak ki, melyek segítségével vállalatuk előnyt kovácsolhat napjaink válság sújtotta társadalmi és üzleti környezetében.

Bizonyítható, ahogy azt Milton Friedman is megtette negyven évvel ezelőtt, hogy mindegy milyen változások mennek vagy mentek végbe a múlt század második felének társadalmi szerkezetében, az üzlet célja ugyanaz maradt. Ez pedig - állítása szerint - újabb érv arra, hogy a vállalatvezetốk az üzlet lényegénél maradjanak, és ne merészkedjenek olyan területekre, melyek nem tartoznak szigorúan a hatáskörükbe. A vállalatvezetóknek a társadalmi ügyeket e terület szakértőire kell hagyniuk, és a részvényeseik felé fennálló egyetlen feladatukkal kell foglalkozniuk, ami nem más, mint az üzlet lényege, az üzlet (Friedman, 1970). Ez talán igaz lehetett fél évszázaddal ezelőtt, ma azonban már nem. A jelenkor nyugati társadalmaiban végbement legalapvetốbb változások egyike az, hogy a közszféra és magánszféra között húzódó fal leomlott (Arendt, 1958). A szexuális forradalommal, a nốk és színesbőrúek társadalmi emancipációjával, a fogyasztás kultúrájával, a modern divattal - hogy csak néhányat említsünk a késó modernitás kultúrantropológiai környezetét formáló trendek közül - feleslegessé vált az értékek és hitek magánszférájának elválása a közszférától, melyben értéksemleges folyamatok biztosítják a közösség politikai kohézióját. A nyilvánosságot elárasztották a határozott értékpreferenciákra épülő személyi és szervezeti identitások, melyek a társadalom más szereplóitốl tiszteletet várnak és azt, hogy a velük való együttmúködés során olyan stratégiákat alakítsanak ki, melyek tiszteletben tartják az ezen identitások alapjául szolgáló értékeket.

Bár homogén világpiac nem létezik, globális kultúra igen, és ez számos kommunikációs csatornán keresztül meg is jelenik. Jóllehet, a globális fogyasztók ízlése és értékrendszere eltérô, életükben ugyanazon globális szimbólumok által megtestesített globális ikonok - globális márkák és vállalatok - vannak jelen. E vállalatok többé nem a fogyasztók felé értéket és cserébe a részvényesek felé profitot továbbító ,szállítószalagok”. Sokkal inkább az interakciók hálójában napjaink társadalmi szerkezetét formáló fontos szereplók. Az értékeket az adott társadalmi szerkezetben közvetlenül részes érintettek határozzák meg a korábbiaknál sokkal komplexebb módon, identitásuk tiszteletben tartását és valamennyi érintetti csoport megbecsülését elérendő pedig bonyolult kapcsolatokat kell menedzselniük. „Számos fogyasztó megilletódik az olyan vállalatok politikai ha- talma láttán, melyek árbevétele meghaladja a kis nemzetek GDP-jének összegét, és melyek komoly befolyással bírnak az emberek életére, a közösségek, nemzetek és végsố soron bolygónk jólétére." (Holt et al., 2004: p. 70.) A 2002. évi Global Brands Study (Globális márkák vizsgálata) szerzói megállapították, hogy az érintettek a globális márkaválaszték három fő jellemzőjét mérlegelve szavaznak és fizetnek: minőségjelzés, globális mítosz és társadalmi felelősségvállalás - globális hatalmuk révén valamennyien kellóen tájékozottak ahhoz, hogy befolyásolják a minket körülölelố világot. Az érintettek véleményt formálnak, ötleteiket és ideáljaikat hatásosan kifejező eszközökkel rendelkeznek, továbbá hatalmukban áll szövetkezni és lehetőségeiket egyéni korlátaikon túlmenően növelni. Ma is ugyanolyan fontos, mint valaha, hogy a vállalatok e változásokat megértsék, mivel a rendelkezésükre álló roppant erőforrásokkal, sikeres múködési gyakorlatokkal és befolyásos kommunikációs csatornákkal ók a leghatalmasabb szereplő́k az interakciók hálójában. A vállalatok széles körú technológiai, innovációs és marketinges képességeiket kihasználva olyan problémákat kezelhetnek, melyekkel a kormányok és az NGO-k évtizedek óta küzdenek. A határozott, értékalapú identitással rendelkezố társadalmi szereplôk olyan egyéni vagy szervezeti érintettek, akik a vállalatokkal különféle csatornákon kommunikálnak. Többé nem fogadják el, hogy két külön világban élnek: egy otthon és az egykori magánszféra más területein a XXI. századi késő modern világban, ahonnan időgépen egy XVII. századi világba utazhatnak, ahol az egykori közszféra uralkodói a nekik munkát adó, velük szerzôdő és kommunikáló vállalatok voltak.

A modern kapitalizmus születésének intellektuális és társadalmi kontextusát adó modernitás/felvilágosodás/ipari forradalom legfontosabb jellemzóje a közterek „felemelkedése”. Habermas szerint a „polgári nyilvánosság" egy egyenlőségre törekvő, befogadó és kritikus „kommunikációs világot alapozott meg, melyben újfajta vitaarénák, a városi közterek és a társasági élet nyitottabb és hozzáférhetóbb formái jelennek meg, továbbá a nyomtatott kultúra is robbanásszerú terjedésnek indult" (Melton, 2001: p. 4.). Így teremtve új fórumot, mely a politikai/társadalmi/közgazdasági tudás és eszmecsere fejlődését segítette elő. A közszféra koncepciója Kant azon eszményére alapul, mely szerint a racionalitás, illetve az ész és a bölcsesség az embert megszabadítja önként vállalt tökéletlenségétôl, a gondolkodás racionális eszmecseréhez vezet, mely végül szerződéses társadalmi, politikai és üzleti együttmúködési formákat eredményez. Az ésszerúség felsóbbségébe vetett hit és az igazság intellektuális, nem transzcendentális keresése elốmozdította a bizalom egy új 
formájának megjelenését, mely átformálta az intellektuálisan egyenlőségre törekvố közszféra kontextusát. A bizalomnak e fogalma az igazság univerzális természetében és lokalizálhatóságában/fellelhetôségében gyökerezik, mely igazság révén mindennemú vita és konfliktus elrendezhetô. Az igazság lehetséges konfliktusok és viták megoldása során történő kereséséhez a közszférának folyamatosan megbízható és hiteles információkra volt szüksége. Az igazság a mindenkor, minden csatornán és számos hiteles forráson keresztül elérhetô egyre növekvô számú információra alapult. Ez volt az információs kor.

A társadalmi-politikai rendszer fejlődéséból kiindulva a XXI. századi késó modern korban három lényegi nézópont jelent meg, melyek a jelen nyugati társadalmi berendezkedés alapjául szolgálnak és az identitások kapcsolataiban meghatározzák az elköteleződés szabályait.

Liberális demokrácia. A késố modern nyugati társadalmak politikai struktúrája liberális demokrácia, ahol a fékek és ellensúlyok garantálják, hogy a közösség valamennyi tagja részt vehessen az önnön kormányzásáról szóló döntési folyamatban. A liberális demokráciákban biztosított az általános választójog, és a döntéseket a közösség felnőtt tagjai hozzák. A liberális demokráciák alkotmánya garantálja, hogy a közösséget irányítók felhatalmazásukkal vissza ne éljenek, a hatalmi ágak egymástól elváljanak, a közösség által elfogadott és legitimált igazságszolgáltatás független legyen, valamint múködjön a fékek és ellensúlyok rendszere a hatalmi ágak pártatlan természetét biztosítandó. Az értékalapú jogokat és szabadságokat korlátozzák azok a bürokratikus folyamatok, melyek megteremtik az egymást kölcsönösen kizáró értékrenddel bíró társadalmi szereplő́k közötti megegyezési alapot (modus vivendi) és - amennyiben a közösség azt úgy akarja - megváltoztatják e modus vivendit.

Pluralista értékrend. A XXI. századi nyugati társadalmak értékrendje pluralista, azaz e társadalmakban nincsen egyetlen, univerzálisan elfogadott és a közösségen kívül legitimált, valamint néhány tag által kontrollált hatalom erejével kikényszerített értékrendszer. Megférnek egymás mellett az egymást kölcsönösen kizáró értékek - így a nôk saját testük és a várandósság elsố pillanatától kezdődően egy új élet fölötti rendelkezési joga -; a morális döntések egyenlő és mindenféle hatalmi játszmáktól mentes, ésszerú diskurzus iránt elkötelezett szereplő́k megegyezésére alapulnak. A morális döntések kontextusfüggók és pragmatikusak: az általam képviselt értékek ugyanolyan értékesek, mint az általad képviseltek - és még akkor is rendíthetetlenül kiállhatunk mellettük, ha tudjuk, hogy viszonylagos természetúek.
Interaktív médiakultúra. A web 2.0 megoldások megjelenésével a tömegkommunikációban a média többé már nem „egy a többhöz” típusú kommunikációs eszköz. A web 2.0 a kommunikációt, információmegosztást, közös munkát, közös alkotást és együttmúködő készséget elősegítő webalapú rendszerként írható le. Az üzenetküldés régi módszerei, az információáramlás és párbeszéd felügyelete utat nyitott az információcsere új formái előtt, lehetôvé téve, hogy a részt vevô szereplốk sokkal szabadabban választhassák meg a bizalom általuk preferált forrását, csatornáit és mélységét.

A paradigmaváltás jellemzóen változást hoz azon bizalom eredőiben is, melyek a mára már globálissá vált közszférában zajló interakciók és identitáskapcsolatok alapját képezik. Az információs kor utat nyitott a közösségek kora előtt, melyben a viták és eszmecserék a bizalom közösségi jellegében gyökerezô, és természetüknél fogva feltételes értékeket, megállapodásokat és szerződéses kapcsolatokat eredményezhetnek. A szerződéses kapcsolatok céljából indított, hatalmi befolyástól mentes eszmecseréhez szükséges bizalom a közösségek korában nem az intellektuálisan hiteles forrásokból érkezô racionális információból származik. E bizalom eredôje az érintetti kapcsolatok közössége, melyben az interakciók alapját a más érintettekkel való kölcsönösen nem kizárólagos, nyitott, és nem szabályszerú párbeszédekben való elköteleződés jelenti. Az érintetti kapcsolatok, a közelség és fontosság fokai az érintettek egymásra gyakorolt befolyásától és hatásától függnek. A bizalom közösségi alapú, és az kizárólag az érintettek közösségének megítélésére van bízva. A verseny, a modern kor egyik sarokköve, átalakult. A ,last man standing” győztes mindent visz versenyfelfogása egyfajta versengve együttmúködésbe váltott, melyben a verseny együttmúködést hangsúlyozó megközelítései ma már inkább általánosnak, mintsem kivételesnek mondhatók. A modernitás régi - különösen marxista - kritikusai a versenytól teljes egészében meg akartak szabadulni. A CSR újabb lehetőséget nyújthat a verseny értékeinek (innováció, kreativitás és haladás) megtartására, ugyanakkor kiterjesztheti bázisát az érdekelt érintettek egy szélesebb körére.

Nem meglepó, hogy a vállalatok nem XXI. századi elvek szerint múködnek. A vállalatok még mindig kettôs világban élnek: a felvilágosodás és korai újkor politikai és társadalmi berendezkedésének, a felvilágosult abszolutizmusnak az utolsó mentsvárai. A vállalatokon belüli érintetti kapcsolatrendszert nem a liberális demokrácia, értékpluralizmus vagy interaktív médiakultúra vezérli. Valójában épp az ellenkezójéról van szó. A politikai döntéseket néhány kiválasztott hozza, nincs 
általános választójog, de a „kormányt” sem több - még ha korlátozott számú - érintett részvételével tartott választás útján választják, nincsenek fékek és ellensúlyok, melyek a vállalaton belül az egyes hatalmi ágak pártatlanságát biztosítanák. Az értékalapú jogokat és szabadságokat nem korlátozzák demokratikus és bürokratikus folyamatok, melyek gondoskodnak a vállalat egymást kölcsönösen kizáró értékeket képviselő érintettjei közötti modus vivendiról, illetve ilyen, a modus vivendit megváltoztató folyamatok sincsenek arra az eshetôségre, ha a közösség eltérố stratégiát kívánna választani. A vállalat aktuális érintetti kapcsolatrendszerén belül nem létezik az értékek pluralizmusa: egy érintetti csoport, azaz a részvényesek által központilag meghatározott és egy másik érintetti csoport, a menedzsment által elfogadott értékek uralják azokat. Ezen értékek néhány tag uralta hatalom erejével érvényesíthetốk. A morális döntések a hatalmi pozícióban lévoók által megfogalmazott ítéletekre alapulnak, mindenféle egyenlő és mindenáron győzni törekvő, racionális eszmecsere nélkül. A morális döntések függetlenek a kontextustól, és egyetlen célt szolgálnak: a vállalati abszolutizmus arisztokráciájának, azaz a menedzsmentnek a jóllétét. Nincs interaktív média: az üzenetküldés az „egy a többhöz" csatornákra épül, az információáramlás szigorúan ellenőrzött és központosított, a web inkább platformként, mintsem koncepcióként történő alkalmazása jellemző, és a kommunikáció legfóbb szerepe abban áll, hogy a hatalommal rendelkezó érintettek üzeneteit közvetítse az információval nem rendelkezó beosztott érintettek felé.

Az érintettek törvényszerúen kettôs világban élnek: a vállalati szférán kívül XXI. századi késô modern korban/liberális demokráciában, ugyanakkor számos érintetti kapcsolatuk a XVII. századi felvilágosult abszolutizmusban ragadt. Az alkalmazottakhoz hasonlóan ók is a felvilágosult abszolutista uralkodó, azaz a vezérigazgató és/vagy az igazgatóság elnöke és az ôt körülvevő arisztokrácia és nemesség alárendeltjei. Még az arisztokrácia is kettôs világban él: a vállalati világban hatalommal bír, ugyanakkor családi életében számkivetett. Ezen arisztokrácia tagjaival gyermekeik gyakran - mert más generációt és értékvilágot képviselnek - nem beszélnek, és megvetik óket, amiért kíméletlen őskapitalistákként rombolják a Földet és a meg nem született jövő generációk életét.

A történelmi analógia túlzott elnyújtása nélkül, mindannyian tudjuk, mi történt az arisztokráciával a XIX. századi forradalmak idején. A gazdasági javakban bővelkedő, ám politikai erejétől megfosztott polgárság átvette a vezetést. E forradalmak kiterjesztették a felvilágosult racionális eszmecserék világát olyan szférákra is, melyek korábban az abszolutista hatalom vagy az egyház kizárólagos fennhatósága alá tartoztak. Ennek ára azonban óriási vérontás és társadalmi felfordulás volt. A CSR a vállalatok világában a „vérontás” nélküli, senki társadalmi státusát vagy egzisztenciáját nem fenyegetô változásra alapuló kiút lehetôségét kínálja.

\section{CSR - a vérontás nélküli forradalom}

A jól körülírt és jól kivitelezett CSR segíthet a vállalatoknak forradalmi energiáik helyett fejlődési energiáikat használni arra, hogy érintettjeiket egy asztalhoz ültessék és elkezdjék átszervezni a vállalat politikájának társadalmi és politikai környezetét. E környezet megváltoztatása nem csupán innovatív vezetést és a létezô CSR-menedzsment alapvetô készségeinek és eszközeinek alkalmazását feltételezi. A paradigmaváltók - mint mindig - most is majdhogynem legyőzhetetlen akadállyal szembesülnek. Meg kell változtatniuk a játék nyelvét és szabályait, miközben a régi játékot a régi nyelven és a régi szabályokkal folytatják. A CSRprojekteket vállalati stratégiába beépító stratégiai CSR nem elegendő. A sikeres projektekkel elért társadalmi hatás még nem jelent paradigmaváltást. Ez még mindig inkább tartalom, mint forma; vállalati abszolutizmus, a felvilágosult fajtából, újratöltve. A vállalatoknak új identitásra van szükségük, ahelyett, hogy identitásukra vonatkozó stratégiájukat definiálnák újra. Rá kell eszmélniük arra, hogy vállalati közösségek, nem pedig királyi házak. A vállalat határai nem ott húzódnak, ahol a királyi várkastély falai véget érnek: az ott kinn, a vállalati parancsnokság sáncain túl nem a hatalom és a reménytelen alattvalók világa, mely arra vár, hogy a marketing-pallos és az értékesítési fegyver leigázza. A vállalat egyben érintettek közössége is. Ezek az érintettek értékeket vallanak, érdekeik és érzéseik vannak; készek belépni a vállalat politikai közösségébe, amennyiben az nem jár szükségszerúen identitásuk feladásával. Minden érintett születésétól fogva egyenlő. Érintetti szerepükben és identitásukban is így kell ôket kezelni: fontos, hogy szabadon kifejezhessék magukat, és érintettként méltóságuk ne sérüljön. Érintetti jogaikat és szabadságaikat, valamint e jogok és szabadságok gyakorlásának eszközeit is védelem illeti. Az abszolutizmus terhétôl úgy szabadulhatnak, ha az érintettek élvezhetik immáron kiterjesztett nyilvános szférájuk értékpluralizmusának előnyeit. A vállalati közösségek irányítása céljából pedig fontos beiktatni a fékek és ellensúlyok rendszerét. Míg a vállalat kizárólag a részvényesek tulajdonában áll, addig a vállalati közösségek nem, bár politikai menedzsmentjük a vezetók feladata. 
A vállalatirányításnak együttmúkködő irányítási formákat kell alkalmaznia: a döntéshozatal lehetô legtöbb érintettet bevonó, sokkal nyitottabb formáit szükséges kialakítania.

Az érintettek felelősségére is szükség van. Új társadalmi szerződésre, melyet minden egyes vállalati közösség maga fogalmaz meg érintetti párbeszéd és elköteleződés útján. A szervezeti és egyéni érintetteknek el kell fogadniuk, hogy a vállalat azért kér engedélyt a múködésre, mert fenntartható pénzügyi sikerre törekszik. Ezen érintetteknek, ugyanakkor, amikor csekkkönyvükkel szavaznak, rá kell ébredniük, hogy a közös értékeknek ára van. A felelősség is közös - a helyi termék drágább lehet, mint a távolból légi úton érkező áru, a természetes összetevốk és biotermelés produktuma egészségesebb, ám egyben drágább, a jobb, biztonságosabb és rugalmasabb munkakörülmények csökkentik a pénzügyi eredményt, melyet másfajta árazási és jövedelmi stratégiával kell ellensúlyozni. Fontos, hogy az érintettek belássák, ók egyben fogyasztók is. Különböző szerepeikben és érintetti kapcsolataikban a vállalati közösség részeként továbbra is szilárdan ki kell tartaniuk az általuk képviselt értékek mellett.

Az együttmúködó irányítás mai felfogás szerint egyre inkább az intézményi érintettek, azaz a vállalatok, a kormány és az NGO-k együttmúködésének egyfajta irányítási formája (Zadek, 2006). A posztindusztriális társadalmakban a vállalatok mindegyike olyan szervezeti erôt képvisel, mely megakadályozza, hogy a köz többi szereplôjével kiegyensúlyozott és átlátható megegyezést tudjanak kötni. Túl erôsek, túlságosan sok kommunikációs csatorna fölött van ellenőrzésük, valamint páratlanul sok pénzügyi és egyéb forrást képesek mozgósítani céljaik elérése érdekében. Az arénába lépésükkel a játéktér is átalakul. Ezért a vállalatok feladata, hogy belülról alakítsák át magukat abszolutista uralkodói házakból együttmúködve irányított vállalati közösségekké. A vállalati közösségek irányító testületeinek olyan stratégiákat kell kidolgozniuk, melyek révén érintettjeik képviselôi is az asztalhoz ülnek és bekapcsolódnak a döntéshozatali folyamatba. A vállalati igazgatóságoknak megvannak a bevett módszereik arra, hogy a vezetóségen kívüli tagokat, illetve egyes esetekben néhány érintetti - alkalmazotti és részvényesi - csoport képviselooit bevonják. Az irányításnak sokkal kiegyenlítettebbnek kell lennie a hatalom különbözó területei, a bírói, a végrehajtói és a törvényhozói ágak között. A multinacionális vállalatoknál a törvényhozói hatalom szétválása megkezdődött az etikai bizottságok alakulásával, közérdekú bejelentésekkel kapcsolatos gyakorlatok bevezetésével és a törvényi előírások betartását ellenőrző tisztviselő́k (ún. compliance officer) alkalmazásával. Jóllehet, mivel nem létezik független érintetti képviselói testület, melynek e szervek vagy személyek jelenthetnének, az effajta kezdeményezésekkel való kísérletezés hiábavalónak bizonyult a vállalati „bíróság” nyitottabbá tételében. Liberális demokráciákban a felsố vezetô az általa irányítandó politikai közösséget alkotók választott testületének felel. Az érintetti érdekek üzleti döntéshozatalba és múködésbe való beemelése az érintettek erôteljes képviseletét és a vezetốk számon kérhetôségét feltételezi.

A vállalatirányítás nem az egyetlen terület, ahol éppen effajta paradigmaváltás folyik. A vállalati márkák felfogása az elmúlt évtizedben alakult át. A márkák már nem csupán a tulajdon jelölésének és az imázsépítésnek az eszközei, hanem szilárd kulturális gyökerekkel és komplex szervezeti kapcsolatokkal rendelkezó, a közös értékteremtésbe, valamint a kölcsönösen hasznos társadalmi cserébe vetett egyezményes hitre épülő közösségekké váltak. Épp ezért a „márka tulajdonlása vállalatvezetési tevékenység helyett immáron egyfajta tárgyaláson alapuló, a márkának jelentést tulajdonitó, és ezzel a márkához kapcsolódó kellemes asszociációk elóhívására törekvó közös folyamat" (Fagerholm, 2007: p. 32.). A vállalatvezetốk elveszítik a közvetlen kontrollt márkájuk identitása fölött, így a márkák politikai közösségekké válnak, melyek „lehetôvé teszik a szabad és tájékozott márkaválasztást, ezzel segitve az egyéniség meghatározását" (Ind, 2003: p. 18.). A márkázás világának vezetói, mint a Nike, Coke vagy Starbucks, rájöttek, hogy a márkák sikere nem az igazgatóságban vagy marketingosztályokon dôl el. Az együtt alkotás és a „márka megélésének” koncepciója olyan márkaközösségi modelleket kínál, melyek az érintetteknek több értéket teremthetnek, mint a részvényesek tulajdonában álló, és pusztán a részvényesi hozamra összpontosító vállalati márkák. A márkák közössége - éppen úgy, mint a nemzetek - virtuális, ún. elképzelt közösségek (Anderson, 1991), melyek immár nem a vállalat és annak képviselóje, a marketinges tulajdona, hanem a közösségé. Ez természetesen nem iktatja ki a marketingest a folyamatból, csupán más eszközöket ajánl számára, hisz a közösség mozgatása és így a márka erejének fenntartása, növelése - az azonosságtudat felkeltésén és múködtetésén, a rítusok és szimbólumok bevezetésén és üzemeltetésén, valamint a közösség iránti felelősség fenntartásán múlik (Muniz O'Guinn, 2001).

A vállalati társadalmi felelősségvállalás, mint a vállalati múködés új modellje, a márkaközösséget kiterjeszti a vállalati közösségre. A hatásos és módszeres CSR ugyanúgy magába foglal önkéntes tevékenységet, 
mint jogilag és a múköós szempontjából kötelezô gyakorlatokat. Érintettjei születésüktől fogva egyenlők, és fontos részt venniük a vállalat politikájában. Szükséges hozzá a vállalati közösség valamennyi tagjának részvétele és elköteleződése. Egy újabb, az újkor születésének idejéról származó történelmi példaként említhetjük azt is, miként hozott létre az amerikai köztársaság alapítóinak tette és az alkotmány nyitómondata - „Mi, az Egyesült Államok népe..." -, hogyan teremtette meg épp magát a népet a semmiból pusztán a leírtak, kimondottak konstitutív volta okán. E gesztus eredménye a ma a demokrácia csúcsaként emlegetett és modern politikai közösségként ismert igazgatás és nemzet - az Amerikai Egyesült Államok. Az alkotmány, szimpla kihirdetésével, olyan kapcsolati hálót formált, mely korábban nem létező és az alapítás pillanatában előre aligha látható ígéreteket, kötelezettségeket, képességeket és interakciókat vont maga után (McGowan, 1998). Új márkát teremtett, melynek neve „Amerika”. Az amerikai alkotmány kimondta a nép egyedüli politikai felségét. A modern alkotmány rögzíti a kormány jellegét és hatáskörét meghatározó szabályokat és elveket, szabályozza az egyéni és szervezeti érintettek közötti kapcsolatokat csakúgy, mint a vezetók, a törvényhozás és az igazságszolgáltatás között fennálló kapcsolatot. Ez az egyetlen erószakmentes alternatívája a hatalom egyoldalú bitorlásának egy, a vállalati adminisztráción belüli csoport vagy szervezet által. A vállalatoknak a politikai demokrácia és értékpluralizmus XXI. századi elveire épülô hatékony alkotmányra van szükségük a XVII. századi (felvilágosult) abszolutista elveken álló alaptörvény helyett.

Ezen alkotmányok alapját az érintettek szuverenitása, az együttmúködő irányítás és érintetti elkötelezôdés elvei kell, hogy képezzék. Ahhoz, hogy az alkotmányozás folyamata elinduljon, hatékony, többirányú kommunikációra van szükség. Az érintettek teszik a dolgukat - képviselnek, követelnek, (vissza)jeleznek, részt vesznek. A CSR azonban a vállalatok felelôsségvállalásáról szól. Arról, hogy a vállalatok mit tehetnek azért, hogy „vérontás” nélkül, fokozatosan és folyamatosan valósuljon meg a paradigmaváltás. Ehhez nem csupán az (új) üzleti-társadalmi kontextus megértésére van szükség, hanem arra is, hogy az új kontextus eszközeiben - elsősorban a kommunikációban - jártasságot szerezzenek a szereplők. Az érintettek hatékony menedzsmentjének eszköze a hatékony, ám megváltoztatott struktúrájú kommunikáció. Az érintettekkel egyenrangú és uralommentes kommunikációhoz a web 2.0 (many-to-many) elveit alkalmazó, egy mátrix pontjait összekötő, sokirányú és sokoldalú kommunikáció gyakorlatának alkalmazására van szükség (Barabási,
2003). Ez azonban nem elegendő. Ebben a folyamatban a kommunikációnak nem a „valamiról szóló beszéd” formáját kell öltenie, nem csupán a cselekvés megalapozója és irányítója, hanem - Austin beszédaktuselméletének nyomán - a cselekvés maga kell legyen (Austin, 1990). Így az érintettekkel való kommunikáció a vállalati alkotmányozási folyamat alapjául szolgál, melynek során a különböző kommunikációs elvek érvényesítése a liberális demokrácia közjogi viszonyaihoz hasonló vállalati közjog megteremtéséhez, végsố soron pedig az érintetti ,alkotmányos demokrácia” létrejöttéhez vezet.

\section{Egyenrangúság és kommunikáció az érintetti hálózatban}

Az új kommunikációs gyakorlat elvei a következôk:

Megosztás: A vállalat vezetői és az érintettek között jelentős információs aszimmetria áll fönn, így ahhoz, hogy az egyenrangú és uralommentes kommunikáció föltételei fennálljanak, előbb ezen információs aszimmetria csökkentésére van szükség. Ehhez strukturált és összehasonlítható alapokon álló, érintettek számára is értelmezhetố mennyiségú és minőségú információra, valamint - ahol erre szükség van - szakértói értelmezést lehetővé tévő elemzésekre és rangsorokra van szükség. Ezt a célt szolgálják - jelenleg - a nemzetközi standardokra épülő ún. fenntarthatósági jelentések, valamint az ezek alapján készülő rangsorok, értékelések.

Elkötelezés: A kommunikációs aszimmetria enyhítése a vállalat-érintett kapcsolat dinamizálásához vezet. Így az érintetti kapcsolatok alapját az értékek és érdekek kölcsönös artikulációja és képviselete jelentheti, melyben az értékek és érdekek egyeztetése válik a kommunikációs cselekvés céljává. Ezt a célt szolgálják - jelenleg - a különböző nemzetközi szabványokra és folyamatleírásokra épülő érintetti párbeszédfolyamatok, melynek során az érintettek - harmadik, moderáló fél részvétele mellett - lehetôséget kapnak értékeik és érdekeik kifejezésére, a vállalat megfogalmazza az érintettekkel kapcsolatos elvárásait és az érintettek segítségével elérendő üzleti céljait, majd egy párbeszéd során ezeket ütköztetik, és igyekeznek konszenzust kialakítani a közös cselekvés lehetőségeiról.

Bevonás: Az érintetti párbeszéd és egyéb elköteleződés felkeltését célzó kommunikációs gyakorlat elvezet(het) az érintettek formalizált és a vállalati múködésbe beépített bevonódási lehetôségeinek kialakításához, a közös alkotás (co-creation) és a versengóegyüttmúködés (copetition) modelljeinek érintetti szintú alkalmazásához. 
A vállalati alkotmányozási folyamat során a következô elveket és célokat kell szem elôtt tartani annak érdekében, hogy a jelenlegi társadalmi-politikai kontextushoz hasonló érintetti viszonyokat hozzunk fokozatosan létre:

Érintettek szuverenitása. A vállalati közösségek hatalma érintettjeitól ered. Ók azok, akik a közösségben való részvételükkel értéket teremtenek. A vállalati közösségek feljogosítják a vállalatokat arra, hogy e közösségeket „múköódési engedély” formájában irányítsák. A „,múködési engedély” kiadásában ugyanakkor az érintetteknek aktívan részt kell venniük. A kapcsolatrendszerükben gyökerező vállalati közösségek, kulturális entitások alapjául egyezményes értékeik szolgálnak. Ezen értékeket tárgyalásos úton, közösségi rítusokon, szimbólumok használatán és egyéb kommunikációs eljárásokon keresztül határozzák meg és érvényesítik. A vállalati közösség alkotmányos alapokra helyezése a vállalati közösséget megkülönböztető és meghatározó értékek megfogalmazásának első lépése.

Együttmúködó irányítás. Az érintetteknek a vállalat vezetésében a közösséget majdan menedzselő megfelelő képviseletre van szükségük, a múködési engedélyt kibocsátó és mindig meghosszabbító intézményeket kell fenntartaniuk és független igazságszolgáltatást igényelnek a közösség múködését elősegítő részértékek megvitatása és újratárgyalása, valamint a közösség által adott pillanatban elfogadott ideiglenes és állandóan változó értékek érvényesítése céljából.

Érintetti részvétel és elkötelezódés. Minden formának és struktúrának szükségszerú részét képezik az elköteleződésról szóló tanácskozások, melyek abban segítik az érintetteket, hogy egyéni és közösségi szinten egyaránt részt vehessenek a vállalati közösség stratégiáját, politikáját és vezérelveit megfogalmazó döntéshozatali folyamatokban. Fontos meghallani az érintettek hangját, és az érintetteknek képesnek kell lenniük részt venni mindenféle kényszerüségtől mentes eszmecserében, annak érdekében, hogy a vállalati közösség és a közösségi tagság vezérelveiról és politikájáról szabad és tájékozott döntések születhessenek. Fontos, hogy az érintettek eldönthessék, a vállalati közösség tagjának lenni egyéni, illetve közösségi szempontból inkább haszonnal, mint kárral jár-e számukra. Fontos az is, hogy sokoldalú és gyakran komplex érintetti identitásuk beteljesülése érdekében megtalálják az elkötelezódés megfelelő fokát. Az elköteleződés fokai csakúgy, mint kötelező ereje időról időre változhat.

Az új vállalati közösségeket a modern liberális demokráciákban megfelelô módon kell irányítani, együttmúködő irányítási formákat szükséges alkalmazni és fontos az érintetteket bevonni, illetve elkötelezni.
A jelen globális gazdasági válság nagyszerú lehetôség a vállalati és politikai vezetốknek a CSR fejlődését elósegítő cselekvésre, ahelyett, hogy érintetti felkelések prédájául essenek. Láttuk már, milyen ereje van az érintetteknek és mi az eredménye a vállalati közösségek tartózkodó felkelésének olyan vállalatok ellen, mint a Gap, Nike, Shell, Exxon vagy Arthur Andersen. Szigorúbb szabályozási gyakorlatok és közvetlen állami tulajdonjog helyett a vállalatokban egyfajta új alkotmányozási folyamat indítására lenne szükség. Nemzetek feletti testületek bevonhatnak szervezeti érintetteket az együttmúkködő irányítás elveit szem elốtt tartó alkotmányozási folyamatba. E folyamat rögzítheti a vállalati alkotmányok formáit és struktúráit, példákat és jó gyakorlatokat mutathat az alkotmányok kidolgozásához és elfogadhat a nemzeti joggyakorlatba foglalandó kötelezô erejú jogi lépéseket. Ennek egyik kezdeti lépése volt az, amikor 2004-ben az EU elfogadott egy irányelvet, mely elvárást fogalmazott meg a vállalatokkal szemben arra nézve, hogy éves jelentésük múködésükról - így nem pénzügyi ügyeikról is - „megerősített ellenőrzést", azaz végső soron CSR-jelentést is tartalmazzon. A nagyvállalatok egyes esetekben erôs érintetti nyomásra szintén átalakulhatnak, illetve menedzselhetik a már megkezdett átalakulást. Ugyanakkor a paradigmaváltás és a közösség szuverenitásának új koncepciójára alapuló valódi hatalomátvétel csak nagyon kevés vállalati közösségben ment végbe, így például a Patagoniánál (Ind, 2004).

Amint azt néhány olyan márka példája bizonyítja, mely vállalati közösségépítésbe kezdett - például a Google, Timberland, Interface, Seventh Generation, The Body Shop és a Ben\&Jerry's -, nincs eleve konfliktus a versenyképesség növelése és a világ jobbá tétele között, amennyiben az adott márka ôszintén elkötelezi magát az értékteremtés egy más módja iránt. A nyitott, demokratikus és liberális vállalati közösségek nagyobb szabadságot, több választási lehetôséget és jobb életet kínálhatnak valamennyi, a közösséghez csatlakozó érintett számára. Hatalmukban áll emellett dönteni. Lehet, hogy a tulajdonjog és a vállalat pénzügyi befektetéseinek megtérülése továbbra is a részvényesek kezében marad, és óket gazdagítja. Az azonban az érintettek jutalma, hogy önnön identitásukat és egyéniségüket egy sokszínú vállalati közösség tagjaként is megốrzik, és egy összességében jobb világban élhetnek.

\section{Lábjegyzet}

\footnotetext{
Köszönöm Bauer Andrásnak és Lukács Ritának, a BCE Marketing és Média Intézete munkatársainak a tanulmány megírásához nyújtott segítségét.
} 


\section{Felhasznált irodalom}

Accountability (2011): CR Leaders Corner - Jeff Swartz http://www.accountability.org/about-us/news/crleaders-corner/jeff-swartz.html

Anderson, B. (1991): Imagined communities: reflections on the origin and spread of nationalism (Revised and extended. ed.). London: Verso. 224. o.

Arendt, H. (1958): The Human Condition. Chicago: The University of Chicago Press

Arendt, H. (1963): On Revolution. New York: Viking

Austin, J. L. (1990): Tetten ért szavak. Budapest: Akadémiai Kiadó

Barabási, A. L. (2003): Behálózva - A hálózatok új tudománya. Budapest: Magyar Könyvklub

Bonini, S.M.J. - Mendonca, L.T. - Oppenheim J.M. (2006): When Social Issues Become Strategic. The McKinsey Quartlery, 2006. május http://www.mckinseyquarterly. com/Strategy/Strategy_in_Practice/When_social_ issues_become_strategic_1763

Elkington, J. (1998): Cannibals with Forks: The Triple Bottom Line of 21st Century Business. Gabriola Island: New Society Publishers

Fagerholm, H. (2007): Collaborative Branding. Helsinki: Haaga Helia University Publication Series

Ferrell, O.C. - Gonzalez-Padron, T.L. - Hult, G.T.M. - Maignan, I. (2010): From Market Orientation to Stakeholder Orientation. Journal of Public Policy \& Marketing, 29. évf., 1. szám, 93-96. o.

Freeman, R.E. (1984): Strategic Management: A Stakeholder Approach. Boston: Pitman

Holt, D.B. - Quelch, J.A. - Taylor, E.L. (2004): How Global Brands Compete. Harvard Business Review, 2004. szeptember, 68-72. o.

Friedman, M. (1970): The Social Responsibility of Business is to Increase its Profits. The New York Times Magazine, 1970. szeptember 13 .

Ind, N. (2004): Living the Brand: How to Transform Every Member of Your Organization Into a Brand Champion.
London: Kogan Page

Ind, N. (szerk.) (2003): Beyond Branding: How the New Values of Transparency and Integrity are Changing the World of Brands. London: Kogan Page

ISO (2008): 26 000: Guidance on Social Responsibility, Tervezet, 2008. december

Jorgensen, B. (2003): Baby Boomers, Generation $\mathrm{X}$ and Generation Y: Policy implications for defence forces in the modern era. Foresight - The Journal of Future Studies, Strategic Thinking and Policy, 5. évf., 4. szám, 41-49. o.

McGowan, J. (1998): Hannah Arendt: An introduction. Minnesota: University of Minnesota Press

Melton, J.V.H (2001): The Rise of the Public in Enlightenment Europe. Cambridge: Cambridge University Press

Muniz, A.M.Jr. - O'Guinn, T.C. (2001): Brand Community. Journal of Consumer Research, 27. évf., 4. szám (március), 412-432. o.

Payne, A.F. - Storbacka, K. - Frow, P. (2008): Managing the co-creation of value. Journal of the Academy of Marketing Science, 36. évf., 1. szám, 83-96. o.

Porter, M.E. - Kramer, M.R. (2006): Strategy and Society: The Link Between Competitive Advantage and Corporate Social Responsibility. Harvard Business Review, 2006. december, 78-94. o.

United Nations World Commission on Environment and Development (1987): Report of the World Commission on Environment and Development: Our Common Future

Zadek, S. (2006): The Logic of Collaborative Governance: Corporate Responsibility, Accountability, and the Social Contract. Corporate Social Responsibility Initiative Working Paper No. 17, Cambridge, MA: Johns Hopkins University, John F. Kennedy School of Government, Harvard University

Cikk beérkezett: 2012. 2. hó

Lektori vélemény alapján véglegesítve: 2012. 8. hó

\section{E S Z Á M U N K S Z E R Z Ö I}

Dr. Poór József, egyetemi tanár, Szent István Egyetem és Selye János Egyetem; Dr. László Gyula, egyetemi tanár, Pécsi Tudományegyetem; Dr. Beke Jenô, egyetemi docens, Pécsi Tudományegyetem; Óhegyi Katalin, üzletfejlesztési tanácsadó, PhD-jelölt, Szent István Egyetem; Kolbe Tamás, menedzsment-tanácsadó, Larskol Kft.; Dr. Braun Róbert, CSc, egyetemi docens, Budapesti Corvinus Egyetem, Marketing és Média Intézet; Dr. Mikulás Gábor, információs tanácsadó, GM Info Consulting; Kotsis Ágnes, egyetemi tanársegéd, Debreceni Egyetem; Dr. Fiáth Attila, egyetemi docens, Budapesti Corvinus Egyetem Szabályozott Iparágak Kutatóközpont vezetője; Nagy Balázs, senior tanácsadó, Expert Management Consulting Kft.; Tóth Péter, piacmúködtetési és gazdasági vezérigazgató-helyettes, MAVIR Magyar Villamosenergia-ipari Átviteli Rendszerirányító Zrt.; Dóczi Szilvia, kockázatkezelési munkacsoport-vezetô, MAVIR Magyar Villamosenergia-ipari Átviteli Rendszerirányító ZRt.; Dinya Mariann, tanácsadó, Expert Management Consulting; Dr. Frankó Krisztina, egyetemi adjunktus, Debreceni Egyetem 